\title{
GEOLOGIA E PETROLOGIA DO COMPLEXO BÁSICO-ULTRABÁSICO DE PIEN, PR
}

\author{
VICENTE ANTÔNIO VITÓRIO GIRARDI*
}

\begin{abstract}
The Pien complex is characterized by a series of NE-SW trending basic and ultrabasic lenses. The country rock is the Agudos granitic body and, predominantly, extensively developed migmatites with some minor occurrences of granulite. Metaperidotites, metapiroxenites, metanorites, serpentinites and magnesian schists form the ultramafic bodies; hornblende metagabbro is the main constituent of the basic lenses. On the basis of petrographical, chemical and geochronological evidences, the geological history is reconstructed as follows: a sequence of basic and ultrabasic intrusions, probably comagmatic, was followed, during the Transamazonic cycle, by an essentially isochemical high grade (granulitic) metamorphic event. A second metamorphism, at lower temperatures and with water influx, overprinted, the first event, during the Brazilian cycle, and controlled the extensive formation of amphiboles, and perhaps of serpentines and talc, at the expense of the pre-existing mineralogy of the basic and ultrabasic rocks. Regional migmatization and intrusion of the Agudos granite are also related to this Brazilian event.
\end{abstract}

INTRODUÇÃo Nas últimas décadas a literatura internacional vem registrando número crescente de pesquisas referentes ao estudo de associações básicas e ultrabásicas. Além do interesse econômico que tais ocorrências despertam, seu estudo acadêmico tem visado procurar subsídios para a interpretação da mineralogia e estrutura do manto superior e crosta inferior.

Tanto no que se refere à classificação, como no que diz respeito à gênese, o assunto tem despertado inúmeras controvérsias. Wyllie (1967) descreve com muita propriedade a histórica discussão entre geólogos que basearam as conclusões genéticas através de dados de campo e estudiosos que as fundamentaram em condições de estabilidade de associações mineralógicas obtidas em laboratórios.

No Brasil têm sido observadas numerosas ocorrências de rochas ultrabásicas encaixadas no "Complexo Cristalino Indiviso" (Scorza, 1968; Berbert, 1970). De modo geral, tais estudos têm procurado classificá-las e delimitá-las, constituindo exceções as pesquisas visando informaçōes mais pormenorizadas, quer sobre o ponto de vista petrogenético (Renger, 1972), quer sobre o geocronológico (Minioli, 1972).

As principais finalidades do presente trabalho foram pesquisar a geologia e a pétrologia do complexo básico-ultrabásico, entender o tipo de relação petrogenética entre os diversos tipos litológicos e informar sobre a natureza e a sequêencia de eventos qúe o afetaram.

A região estudada é parte da Folha de Pien, cujos limites aproximados são de $26^{\circ}$ a $26^{\circ} 15^{\prime}$ de latitude sul e de $49^{\circ} 15^{\prime}$ a $49^{\circ} 30^{\prime}$ de longitude oeste. A localização geográfica de Pien é mostrada pela Fig. 1.

Geologia local As unidades delimitadas A região de Pien é constituída essencialmente por rochas precambrianas. Inicialmente enquadradas dentro do chamado "Complexo Cristalino Brasileiro", tais rochas foram mais recentemente colocadas dentro do Grupo

* Departanento de Mineralogia e Petrologia, Instituto de Geociências, Universidade de São Paulo, São Paulo, Brasil 


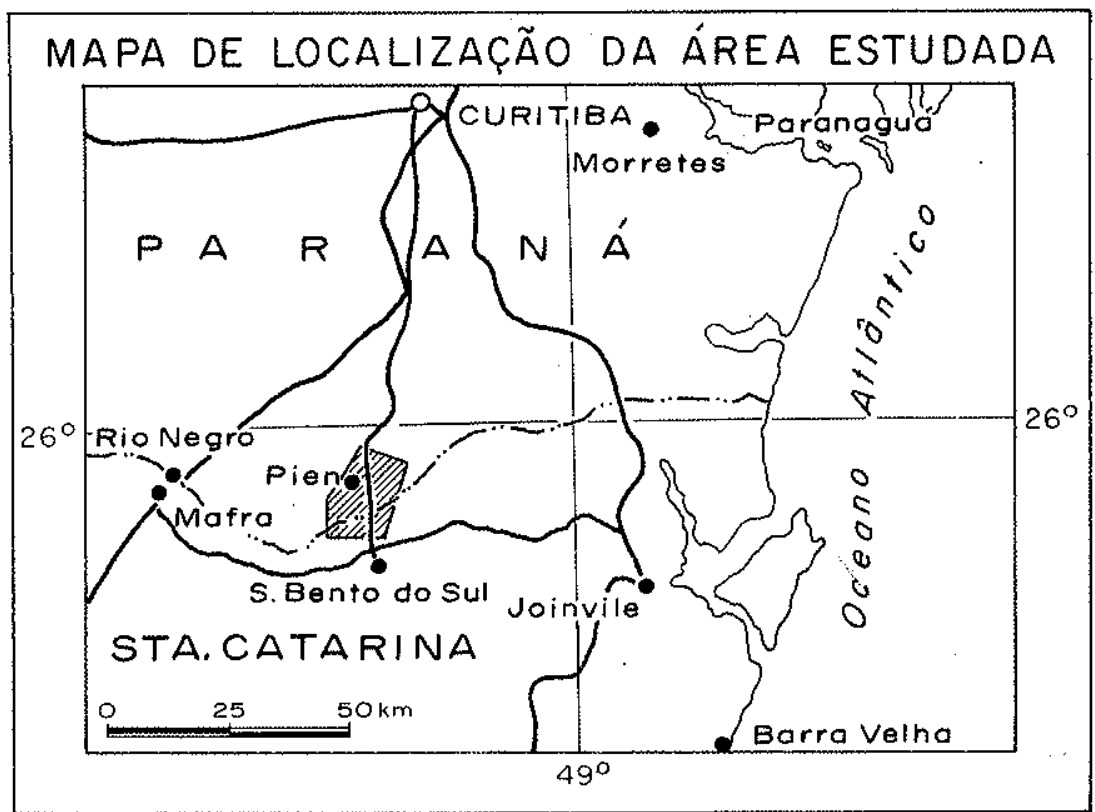

Figura 1 - Mapa de localização da região de Pien

Taboleiro (Schultz et al., 1969), unidade que abrange vasta zona de Santa Catarina e que consta de duas subunidades: rochas migmatíticas indiferenciadas e ultrabasitos, e rochas derivadas, além de alguns itabiritos. Brito Neves e Albuquerque (1973) preferem atribuir ao conjunto a denominação de Complexo Taboleiro.

$\mathrm{O}$ mapa da Fig. 2 mostra que a direção de orientação geral das unidades precambrianas se dá segundo NE. Tal fenômeno é evidenciado quer pela disposição das lentes de rochas básicas e ultrabásicas, quer pelas raras medidas de xistosidade dos migmatitos, ou ainda pelos alinhamentos de feldspatos nos granitos. Foram observadas três direções principais de fraturamento: a mais conspícua, de direção NE, é também representada em outras áreas do Complexo Taboleiro (Albuquerque et al., 1971); a segunda, de direção aproximada $\mathrm{N} 5-15 \mathrm{~W}$ é de importância subordinada enquanto que ao sistema de fraturas noroeste-sudeste se associa a intrusão de diabásios mesozóicos.

Os migmatitos, por serem as rochas mais intemperizadas da região, constituem raríssimos afloramentos. Caracterizam-se pela alternância de bandas félsicas e máficas, aquelas normalmente mais espessas. As faixas claras são formadas essencialmente por quartzo, plagioclásio (oligoclásio-andesina) e feldspato potássico (em geral, microclínio). As várias proporções em que os feldspatos ocorrem definem petrograficamente faixas graníticas a granodioríticas. As texturas são granoblásticas e porfiroblásticas, estas definidas pela presença de cristais de plagioclásio e microclínio com dimensões até centimétricas. Os minerais das zonas escuras incluem biotita, hornblenda, epídoto, plagioclásio (oligoclásio-andesina), allanita, opacos e zircão. Piroxênios do tipo augita-diopsídio e granadas ocorrem em algumas amostras.

Intercalados aos migmatitos observou-se a presença de granulitos ácidos, básicos e intermediários. Os ácidos, raríssimos, são leucocráticos e constituídos essencialmente por mesopertita, cuja quantidade alcança aproximadamente $70 \%$ do volume da rocha, ocorrendo subordinadamente plagioclásio (andesina), ortoclásio e quartzo. Granada, biotita, 
MAPA GEOLÓGICO DA REGIÄO DE PIEN-PARANÁ

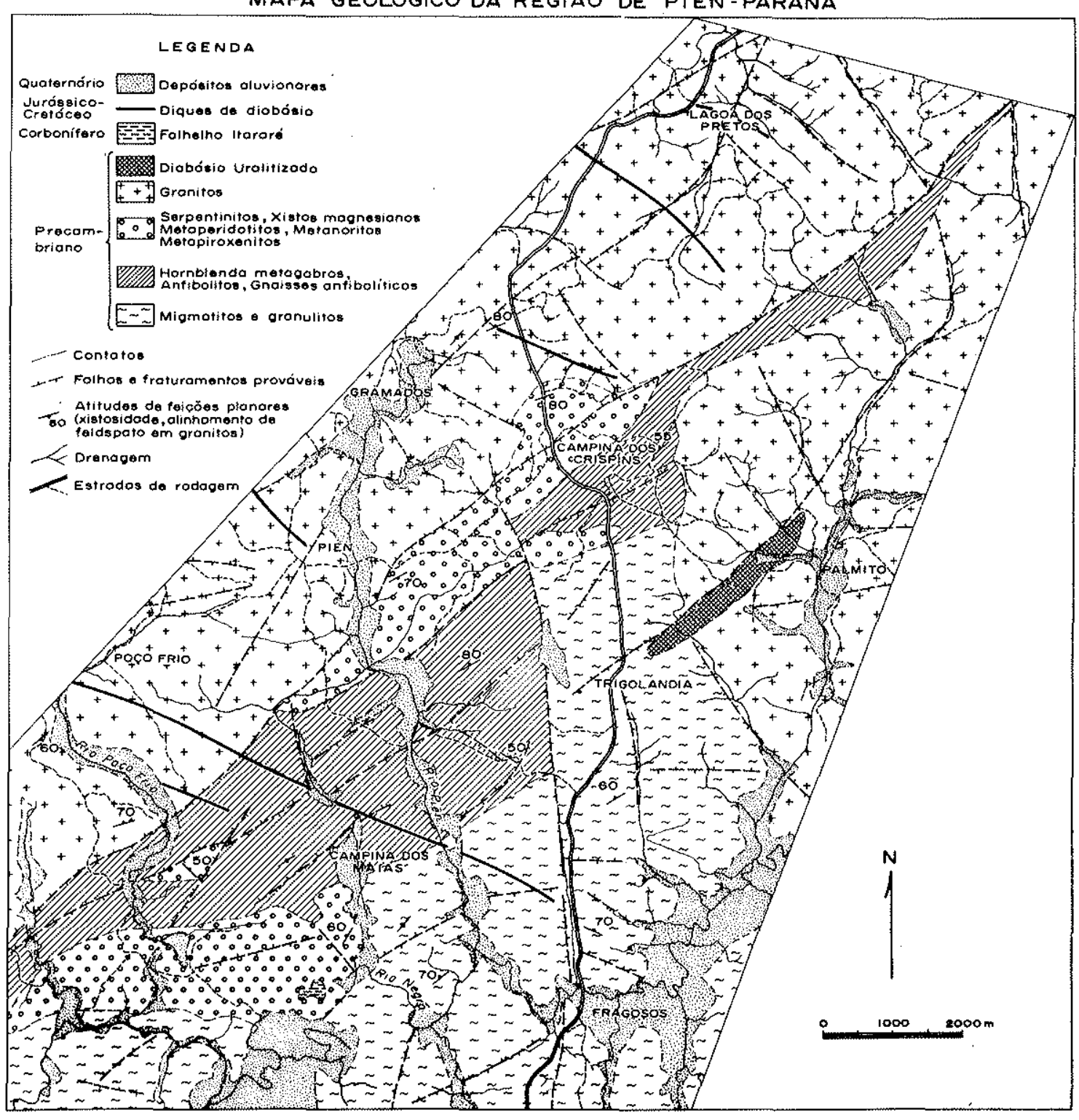

Figura 2 - Mapa geológico da região de Pien

opacos, clorita, apatita, epídoto e zircão são acessórios. A textura é granoblástica. Os granulitos básicos a intermediários são geralmente mesocráticos. Em razăo de sua correlação genética com as rochas básicas e ultrabásicas, os dados referentes à sua mineralogia, petrografia e petrogênese serão tratados posteriormente.

A região central da Fig. 2 mostra a existência de corpo lenticular orientado segundo $\mathrm{NE}$, parcialmente contido em migmatitos e granulitos, e parcialmente no Granito Agudos. Esta lente é constituída por rochas nas quais o par hornblenda-plagioclásio está sempre 
presente em proporções significativas. Dadas as diversas composições modais e principalmente texturais, tais rochas foram denominadas hornblenda metagabros (termo predominante), anfibolitos e gnaisses anfibolíticos. Um dos dados de campo de eventual impor* tância e significação para a discussão da correlação entre rochas básicas e ultrabásicas seria a observação direta dos contatos entre as lentes de hornblenda metagabro e as de rochas ultramáficas. $O$ intenso intemperismo regional impossibilitou tal análise, porém certos fatos são significativos. Em vários afloramentos, dentro do corpo de hornblenda metagabro, ocorrem pequenas intercalações de metapiroxenitos e serpentinitos. Da mesma forma aparecem intercalações de composição gabróide e anfibolítica nas lentes ultramáficas. Essas ocorrências representaram os primeiros indícios da possível consangüinidade entre rochas básicas e ultrabásicas, cujas evidências, de natureza petrológica e química, serão discutidas posteriormente.

A terceira unidade delimitada é constituída por lentes concordantes de rochas predominantemente ultramáficas e ultrabásicas, adjacentes aos hornblenda metagabros, de origem ígnea, cujas litologias refletem as várias fases metamórficas a que foram submetidas. Predominam xistos magnesianos e serpentinitos, ocorrendo subsidiariamente metaperidotitos, metapiroxenitos e metanoritos, em íntima associação.

O granito Agudos, cuja denominação se deve a Fuck et al. (1969), está representado na área por sua porção sul. $\mathrm{O}$ maciço exibe composição variável granítica a granodiorítica, sendo o tipo granodiorítico-adamellítico amplamente predominante. Associados ao maciço ocorrem alguns diques de granitos e granodioritos pórfiros. Os autores que estudaram o Granito Agudos, quer na Folha Geológica de Pien (Trein et al., 1969b), quer nas de Tijucas do Sul (Trein et al., 1969a) e de Mandiruba (Marini et al., 1970), classificaram-no como intrusivo. $\mathrm{Na}$ região objeto do presente trabalho, embora não tenha sido possível a observação de contatos, nota-se que, comparando-se granitos e migmatitos, se conclui que grande parte do maciço exibe textura isótropa, muito embora, em algumas áreas graníticas, como a SW de Pien, haja alguma orientação conferida pelo alinhamento de feldspatos e micas. Tal aspecto contrasta nitidamente com o dos migmatitos, cujo tipo heterogêneo resulta da presença de bandas claras e escuras bem delineadas. Acresce o fato de datações radiométricas $\mathrm{Rb} / \mathrm{Sr}$ acusarem, como se verá adiante, idades diversas para ambas as rochas.

$\mathrm{Na}$ região oriental da área ocorre corpo de diabásio orientado segundo NE. A textura predominante é subofitica; o que mais desperta a atenção nessas rochas é a intensa uralitização a que foram submetidas, resultando a grande quantidade de hornblenda verde, que supera nitidamente a de piroxênios, minerais que thes deram origem.

Ocorrem também na área diques de diabásio, cujas orientações concordam com as estabelecidas no Estado do Paraná, ou seja, N50 60W (Marini et al., 1967). São de idade mesozóica e sua freqüência é bem menor que a de várias regiões paranaenses, como, por exemplo, a de Morretes-Antonina (Cordani e Girardi, 1967).

A evolução geológica Foram efetuados estudos geocronológicos nas unidades precambrianas referidas, através de análises $\mathrm{Rb} / \mathrm{Sr}$ e K/Ar (Girardi et al., 1974). Tais dados permitiram deduzir que após a intrusão básica-ultrabásica ocorreu, durante o ciclo Transamazônico, metamorfismo que recristalizou tais rochas em condições de fácies granulito. Este fenômeno ocorreu há cerca de 2 bilhões de anos. Ainda dentro do ciclo Transamazônico devem ter se formado migmatitos, a se julgar pelas datações obtidas em algumas dessas rochas. A ocorrência de idades transamazônicas, em Pien, Morretes (Cordani, 1971), em Barra Velha (Minioli, 1972) e a existência de charnoquitos em Serra Negra, levou Cordani (1974) a concluir que a região cujo eixo estaria disposto segundo Pien, Morretes, Serra Negra, Jacupiranga, estendendo-se para norte, provavelmente até o maciço de 
Itatins, no Estado de São Paulo, teria se portado como um alto tectônico, durante o final do Precambriano, caracterizado por numerosas exposições do embasamento.

Durante o ciclo Brasiliano ocorreram vários fenômenos na área: a) intensa migmatização regional, datada através de isócrona que apontou idade de 650 m.a.; b) formação do granito Agudos (580 m.a.); c) anfibolitização das rochas básicas granulíticas; e d) intrusão do diabásio uralitizado que ocorre junto a Palmito, cujas datações efetuadas, em plagioclásios e anfibólios, apresentam idades variando entre 435 e 598 m.a.

Após o ciclo Brasiliano, a história geológica da região registra fase de plataforma estável, tendo os sedimentos da Bacia do Paraná (que afloram a oeste de Pien) se depositado após subsidência da área. A injeção de diques de diabásio orientados segundo NW ocorreu durante fase de reativação da plataforma, no Jurássico-Cretáceo. O último evento a registrar-se reside na formação de depósitos aluvionares quaternários.

PETROLOGIA DAS ROCHAS BÁSICAS E ULTRABÁSICAS 1) Descrigão das unidades litológicas No presente capítulo serão descritas as diversas unidades do complexo básico-ultrabásico. Tais rochas, originalmente magmáticas e provavelmente consangüíneas, sofreram no decurso de sua história geológica a influência de várias fases metamórficas.

Grande parte delas, especialmente as de composição peridotítica, norítica, piroxenítica e gabróide, mostra de maneira tão clara a influência da composição magmática inicial que somente através do estudo acurado de particularidades texturais, aliado a outros fatores petrogenéticos, tais como a avaliação de temperaturas de formação de minerais (Girardi, 1974), foi possivel deduzir-se a existência de recristalização metamórfica. Nesses casos julgou-se conveniente a utilização do prefixo meta acrescido do nome da rocha ígnea original.

Granulitos básicos e intermediários Granulitos de composição básica a intermediária ocorrem entremeados aos migmatitos regionais. Trata-se de rochas de aspecto predominantemente isótropo, embora algumas amostras xistosas tenham sido observadas. No que se refere à coloração são comumente mesocráticos. Tipos leucocráticos são raros. Plagioclásios e piroxênios são os minerais predominantes, constituindo pelo menos $70 \%$ da rocha. Quartzo, feldspato potássico, opacos, anfibólio, clorita, serpentina, dolomita, biotita, talco, apatita, epídoto, zircão e granada ocorrem subordinadamente. Alguns desses minerais ocupam lugar de destaque em determinadas amostras, sendo inteiramente ausentes em outras. A quantidade de plagioclásios e o teor de $\mathrm{An}$, que varia de $\mathrm{An}_{33}$ a $\mathrm{An}_{65}$, aumentam concomitantemente com a basicidade dos granulitos. Geminação segundo a lei da albita é freqüente nesses minerais. A ocorrência de indivíduos geminados segundo albita-Carlsbad e periclínio é bem menos freqüente. Por vezes notou-se a presença de epídoto proveniente de plagioclásios, fenômeno indicativo de retrometamorfismo. Intercrescimentos antipertíticos são comuns. Ocorrem dois tipos de piroxênios: os monoclínicos e os ortorrômbicos, predominando ora um, ora outro. Os ortopiroxênios são os mais ricos em ferro dentre os existentes no complexo básico-ultrabásico. Correspondem a hiperstênios até o limite com ferro-hiperstênios (Girardi, 1974). Pleocroísmo rosa a incolor é comum nesses minerais, que, quando alterados, dão origem a talco e serpentina, que ora bordejam, ora cortam os piroxênios segundo as linhas de clivagem ou de partição. Os clinopiroxênios são incolores ou levemente esverdeados. Exibem, a exemplo dos orto, relativa riqueza em ferro, sendo classificados como salitas. Anfibólios, produtos retrometamórficos de clinopiroxênios, aparecem em quantidades expressivas em algumas amostras. Tais minerais, que bordejam os clinopiroxênios, exibem $\mathrm{Z}=$ verde escuro; $\mathrm{X}=$ amarelo. A única amostra analisada (Girardi, 1974) permite classificar a espécie como magnésio- 
-hornblenda, segundo Leake (1968), ou como hornblenda, de acordo com Deer et al. (1963). Feldspato potássico ocorre em duas amostras. É intersticial e exibe geminação gradeada difusa. Quartzo ocorre em amostras onde se notam indícios de xistosidade, dispondo-se, por isso, em faixas alongadas. Opacos são acessórios sempre presentes, predominando titanomagnetita e ilmenita. A textura é granoblástica e as dimensões dos minerais variam, em geral, ao redor de 0,3 a $1 \mathrm{~mm}$. É comum a ocorrência de ângulos de $120^{\circ}$ entre os limites externos dos grânulos (Fotomicrografia 1), fenômeno, segundo Kretz (1966), característico de recristalização metamórfica.

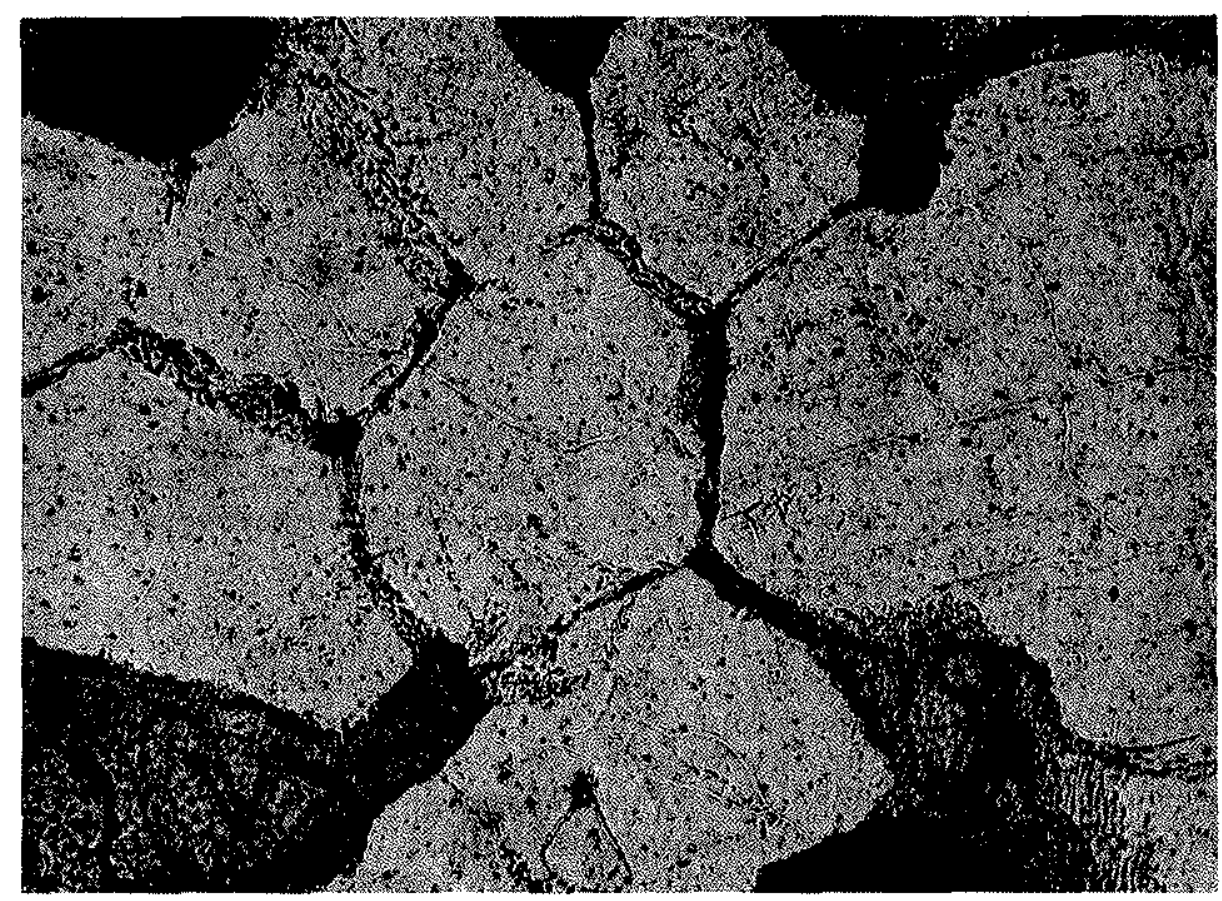

Fotomicrografia 1 - Cristais de plagioclásio exibindo textura granoblástica. Os ângulos entre os limites dos grânulos são de aproximadamente $120^{\circ}$. Rocha: granulito; aumento: $250 \times$. Nicóis descruzados

Metaperidotitos Metaperidotitos, metanoritos, metapiroxenitos, serpentinitos e xistos magnesianos, a serem discutidos a seguir, estão intimamente relacionados, constituindo pequenas lentes adjacentes às de hornblenda metagabro e rochas associadas.

Ortopiroxênios e olivinas predominam nos metaperidotitos. Clinopiroxênios, espinélios, opacos e serpentinas são minerais subordinados de presença constante, sendo talco e dolomita acessórios raros. $\mathrm{O}$ alto teor em magnésio dessas rochas é exibido por seus minerais mais comuns; os ortopiroxênios e os clinopiroxênios, opticamente incolores, são representados, respectivamente, por bronzitas, até o limite com enstatita, e por diopsídios (Girardi, 1974); as olivinas são termos limítrofes entre forsteritas e crisolitas. Magnetita, o mineral opaco presente, está comumente associado a espinélio verde, classificado como pleonasto (Girardi, 1974). Serpentina origina-se geralmente de olivina. Os piroxênios, se bem que, por vezes, parcialmente serpentinizados, são muito menos sus- 
cetíveis ao fenômeno. Talco ocorre somente em uma amostra e é resultado da alteração de ortopiroxênio. A granulação dessas rochas varia comumente em torno de $0,3-0,8 \mathrm{~mm}$. A textura é granoblástica, sendo comum a ocorrência de ângulos de $120^{\circ}$ entre os minerais. Além desse, outro fenômeno textural parece evidenciar recristalização metamórfica. Trata-se da presença de olivina envolvendo ortopiroxênio, fato obviamente não explicável através de cristalização magmática normal (Fotomicrografia 2).

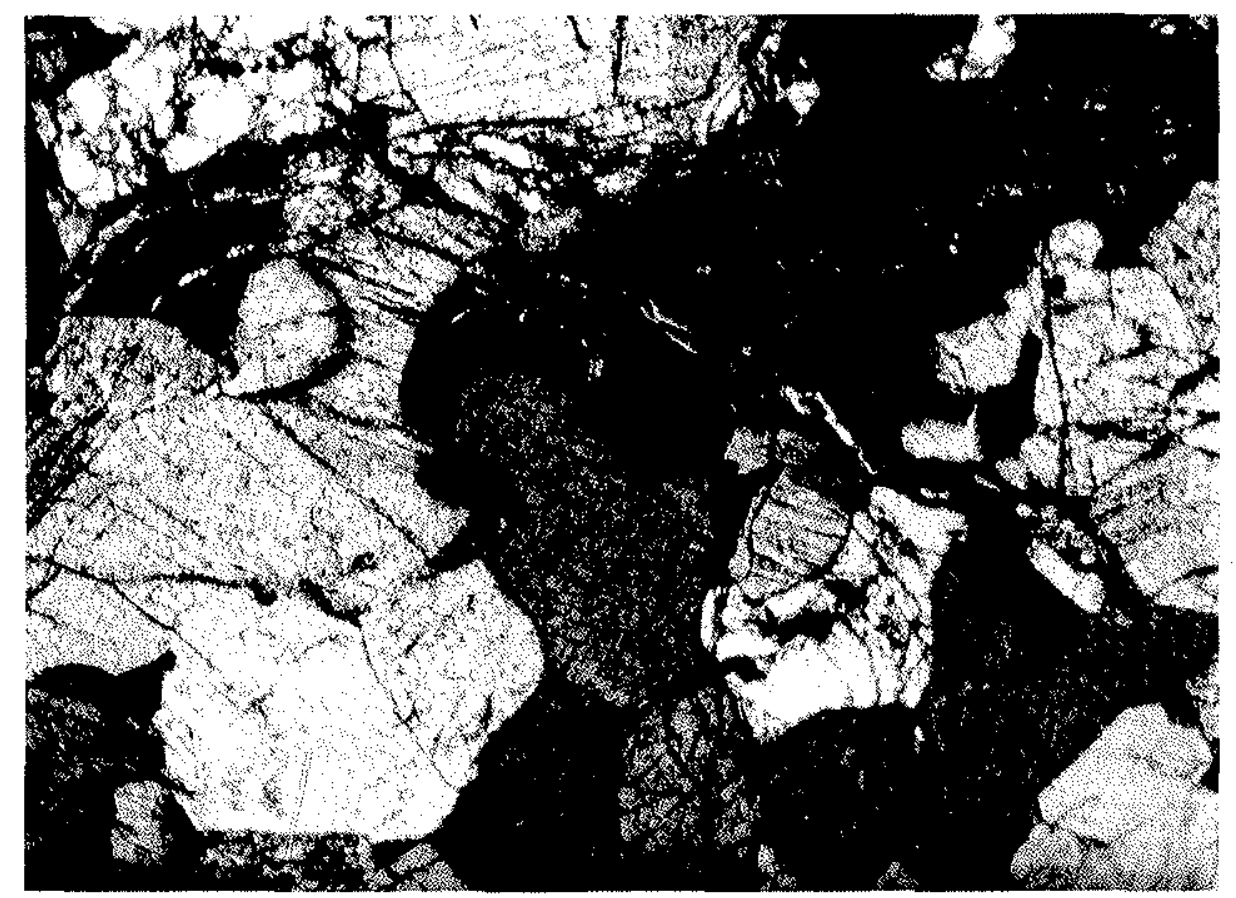

Fotomicrografia 2 - Olivina (extinta) envolvendo piroxênio. Rocha: metaperidotito; aumento: $125 \times$. Nicósis cruzados

Metapiroxenitos As análises dos metapiroxenitos estudados evidenciaram amplas variações percentuais dos piroxênios monoclínicos e ortorrômbicos. Enquanto em algumas amostras suas quantidades são semelhantes, em outras nota-se acentuado predomínio, ora de um, ora de outro. Lamelas de exsolução de clino em ortopiroxênios são raras, o que evidencia a notável separação das fases mineralógicas. Os clinopiroxênios pertencem às variedades diopsídio e salita enquanto os ortopiroxênios são representados por bronzitas. Foram observados dois grupos de anfibólio: um deles com $\mathrm{Z}=$ castanho, $\mathrm{X}=$ amarelo e outro incolor fibroso. $O$ primeiro tipo foi analisado em duas amostras (Girardi, 1974). De acordo com Deer et al. (1963) tais minerais situam-se um no campo das pargasitas e outro entre hornblenda e pargasita. Se adotada a classificação de Leake (1968), os minerais denominar-se-iam hornblenda tschermakítica e pargasita ferrosa, respectivamente. $O$ segundo tipo não foi analisado quimicamente, porém suas características ópticas indicam tratar-se de membro da série tremolita-actinolita. No que diz respeito à origem, os anfibólios incolores e fibrosos são secunclários, sendo clara sua proveniência a partir de piroxênios. Nas variedades castanhas as relações não são evidentes. Enquanto em algumas 
amostras tais minerais bordejam fraturas de piroxênios, em outras anfibólios e piroxênios estão em aparente equilíbrio. E possível, portanto, a ocorrência de duas gerações de anfibólios castanhos. Titanomagnetita e ilmenita são opacos mais comuns. Pequenas quantidades de plagioclásios $\mathrm{An}_{45}-\mathrm{An}_{60}$ foram observadas em algumas amostras; serpentina, talco e clorita são minerais de alteração, provindo os dois primeiros de piroxênios e o último também de anfibólios. As texturas são comumente granoblásticas, ocorrendo muitas vezes ângulos de $120^{\circ}$ entre os contatos dos minerais (Fotomicrografia 3). A granulação dos minerais varia em média de 0,2 a $1,2 \mathrm{~mm}$. Textura porfiroblástica foi observada somente em uma amostra, a única portadora de granada. Tal mineral ocorre sob a forma de porfiroblastos de ate $5 \mathrm{~mm}$ de diâmetro, incluindo poiquiloblasticamente piroxênios e outros minerais constituintes.

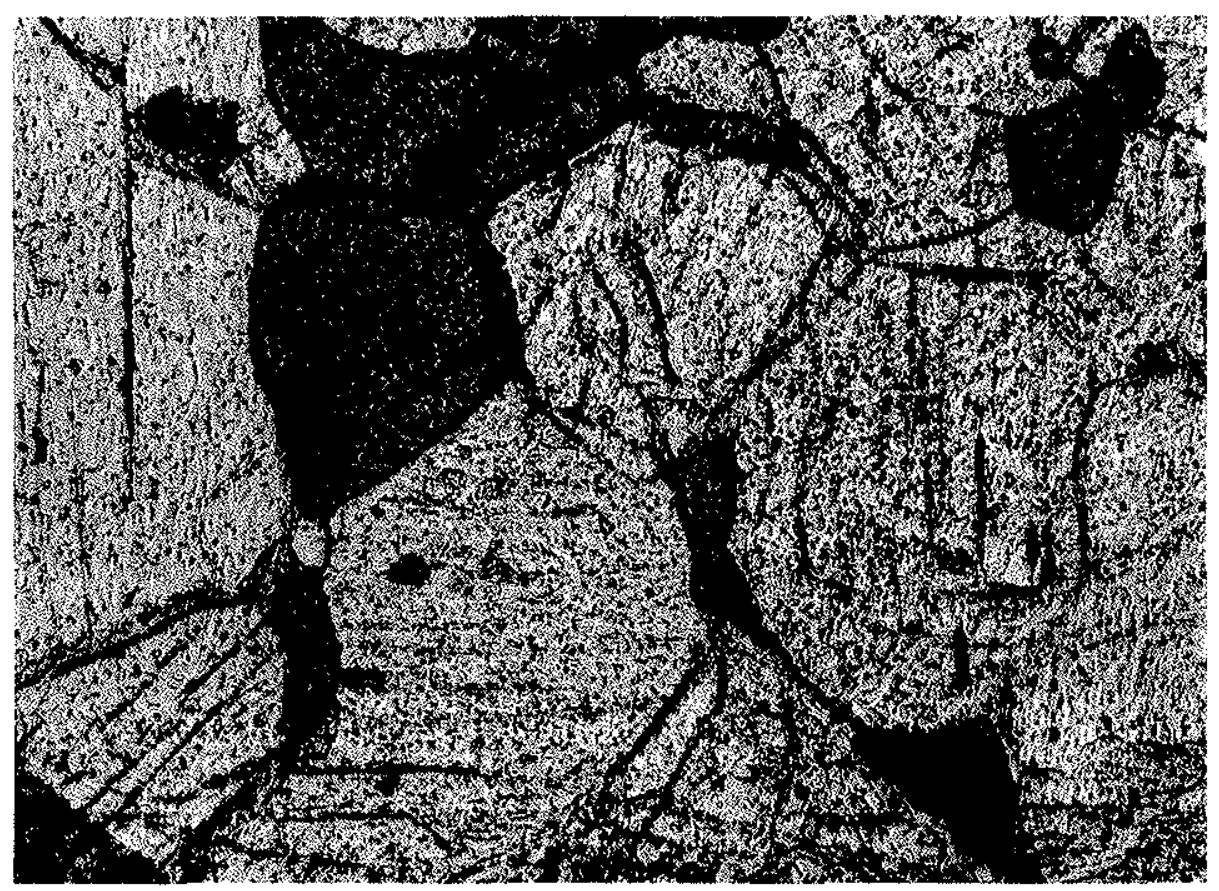

Fotomicrografia 3 - Cristais de piroxênio cujos limites formam ângulos de $120^{\circ}$. Rocha: metapiroxenito; aumento: $300 \times$. Nicóis descruzados

Metanoritos $\mathrm{O}$ aumento da quantidade de plagioclásio em rochas constituídas essencialmente por piroxênios dá origem ao aparecimento de rochas de composição já norítica. Nelas, os ortopiroxênios assumem proporções predominantes e variam de $52 \%$ a $64 \%$. Clinopiroxênicos estão sempre presentes em quantidades expressíveis, porém subordinadas ao tipo ortorrômbico. Espinélio, opacos e anfibólios são acessórios comuns, ocorrendo raramente talco e dolomita. Os piroxênios rômbicos, geralmente incolores, são bronzitas. $\mathrm{O}$ teor de anortita nos plagioclásios varia de $\mathrm{An}_{45}$ a $\mathrm{An}_{60}$. Geminação segundo a lei da albita é freqüente ocorrendo a lei do periclínio em somente uma amostra. Os anfibólios têm $Z=$ castanho-claro e $X=$ incolor. As análises químicas efetuadas (Girardi, 1974) permitem classificá-los como pargasitas a hornblendas tschermakíticas. A origem dos 
anfibólios não é muito clara. Enquanto em algumas amostras parecem ser primários, estando aparentemente em equilíbrio com os demais minerais, em outras provêm da transformação dos piroxênios. As pequenas quantidades de anfibólios nas diversas seções estudadas impediram a análise e a definição mais precisa. $O$ espinélio (hercynita) está comumente associado a opacos, estes comumente representados por titanomagnetita, cromita, ilmenita e pirita. A granulação dessas rochas varia ao redor de 0,3-1,3 mm em média. A textura é granoblástica e ângulos de $120^{\circ}$ foram observados entre os limites externos dos grânulos. Junto à estrada principal a crrca de $1,2 \mathrm{~km}$ ao norte de Trigolândia, ocorre, entremeada aos granulitos, rocha caracterizada pela presença predominante de ortopiroxênios, ocorrendo subordinadamente safirina e plagioclásio; e, em quantidades menores, espinélio, granada, anfibólio, talco e clorita. A presença de safirina, cuja ocorrência mais comum está ligada a rochas granulíticas, foi discutida por vários autores (Allard e Fujimori, 1966: Stormer Jr., 1973: Wilson e Hudson, 1967; Den Tex, 1971).

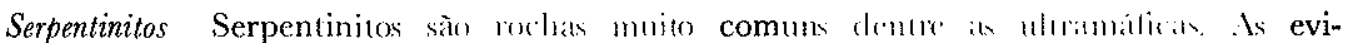
dências texturais mostram que grande parte deles deve ter-se originado de rochas ricas em olivinas de composição provavelmente dunítica, se bem que as de composição peridotítica também contribuíram para sua formação. Tal fato é comprovado pela ocorrência comum de restos de piroxênio, que, mais resistentes à serpentinização, prevalecem sobre os cristais reliquiares de olivina. Serpentina, opacos, talco, dolomita e espinélio são os demais minerais existentes. As serpentinas são representadas pelos seus três polimorfos, sendo lizardita o mais freqüente, seguido por crisotila e antigorita. Magnetita, cromita e hematita são opacos mais comuns. Vários tipos de relações texturais foram observados:

a) Lizardita sob forma de pequenas fibras, cuja disposição causa comumente polarização do agregado. Em outras amostras, os minerais arranjam-se, muitas vezes, sob forma de camadas concêntricas. Junto aos contornos externos do mineral original (olivina mais freqüentemente e também piroxênio) é comum a presença de opacos (magnetita) segregados, subprodutos da transformação de olivina ou piroxênio em serpentina.

b) Placas grandes de lizardita substituindo pseudomorficamente antigos máficos.

c) Serpentina placóide, usualmente lizardita, recortada por áreas de serpentina fibrosa (crisotila) formando malhas (mesh structure).

d) Veios de crisotila, representantes provavelmente de geração tardia de serpentina, cortando irregularmente as amostras.

e) Antigorita fibrosa pseudomorfa sobre piroxênios dando origem à textura "bastítica".

A presença de várias amostras de serpentinitos cisalhados reflete a ação de processos tectônicos.

Xistos magnesianos Talco e clorita são os minerais mais importantes dos xișla magnesianos. Opacos são acessórios comuns, sendo observados também, esporadicamente, rutilo, turmalina e quartzo (este somente em uma amostra). Talco, sempre presente sob forma de delgadas placas incolores, substitui pseudomorficamente, em várias amostras, antigos máficos, provavelmente piroxênios. As cloritas são geralmente esverdeadas, exibindo sinais opticos ora positivos, ora negativos. Ocorrem, ora entremeadas ao talco, ora formando "ilhas" em meio à massa constituída por esse mineral. Nesse caso estão comumente associadas a opacos, sendo o conjunto pseudomórfico sobre antigos máficos. Em alguns casos foram observados porfiroblastos pleocróicos de até $1 \mathrm{~mm}$ de comprimento. Parece haver duas gerações de tremolita. A mais comum, anterior ao talco e à clorita, provavel. 
mente descende das ultramáficas originais; a outra, cujos minerais têm dimensões menores (até $1 \mathrm{~mm}$ ), forma microporfiroblastos, em meio à massa fundamental, que tem no talco e na clorita os principais constituintes. As texturas são comumente lepidoblásticas, ocorrendo por vezes as porfiroblasticas, caracterizadas por porfiroblastos de clorita e tremolita acima mencionados.

Hornblenda metagabros, anfibolitos e gnaisses anfiboliticos Dadas as diferenças texturais e mineralógicas entre as rochas básicas de grande lente central da região de Pien, foram-lhes atribuídas diferentes denominações.

Os hornblenda metagabros constituem os tipos mais abundantes. Caracterizam-se mineralogicamente pela presença constante de plagioclásios e anfibólios, e em grande parte das amostras de clinopiroxênios. Clorita, opacos, granada, epídoto, apatita, biotita, quartzo, titanita, e prenhita são acessórios. Os plagioclásios variam de $A_{30} \mathrm{a}_{30} \mathrm{An}_{72}$. Ocorrem dois grupos de anfibólios: um com $\mathrm{Z}=$ castanho, $\mathrm{X}=$ amarelo e outro com $\mathrm{Z}=$ verde-claro a incolor, $\mathrm{X}=$ amarelo e hábito freqüentemente acicular. $\mathrm{O}$ primeiro tipo foi analisado em quatro amostras, sendo classificado como pargasita, ou variando de pargasita a hornblenda, segundo Deer et al. (1963); ou como pargasita ferrosa e hornblenda tschermakítica de acordo com Leake (1968). O segundo tipo não foi analisado quimicamente, porém suas características ópticas indicam tratar-se de membro da série tremolita-actinolita. Sua origem é claramente sccundária, proveniente de clinopiroxênios ou de anfibólios castanhos. Estes, por sua vez, parecem pertencer a duas gerações, uma primária, aparentemente menos abundante, e outra secundária, derivada de clinopiroxênios salíticos. Nas granadas, por vezes parcialmente cloritizadas, predominam as moléculas almandina e piropo (Girardi, 1974). Epídotos são raramente primários. Provêm geralmente da transformação de anfibólios, através da reação anfibólio $\rightarrow$ epídoto + + clorita + titanita ou de plagioclásios. Clorita e biotita também são secundárias. Titanomagnetita e pirita predominam entre os opacos. A textura é granoblástica e a granulação está por voltá de 0,5 a $1,5 \mathrm{~mm}$. As evidências petrográficas mostram que, após sofrerem metamorfismo no fácies granulito, os gabros originais foram afetados por evento retrometamórfico cuja principal consequiência foi a anfibolitização dos clinopiroxênios, acompanhada também por fenômenos menos importantes como formação de epídoto, biotita e clorita secundários.

Sob o nome de anfibolitos foram reunidas as rochas de textura nematoblástica, nas quais os anfibólios são largamente predominantes. Plagioclásios ocorrem em algumas amostras sendo ausentes em outras, o mesmo ocorrendo em relação aos clinopiroxênios. Clorita, opacos, granada, epídoto, apatita e biotita são acessórios. Foram determinados nestas rochas dois tipos de anfibólios: castanhos (pargasitas e pargasitas ferrosas) e verde-claros a incolores (tremolitas-actinolitas), cujas relações texturais são idênticas às existentes nos hornblenda metagabros. Os clinopiroxênios aparecem geralmente sob forma de núcleos reliquiares enquanto os plagioclásios variam de $A_{35}$ a $A_{60}$.

Os gnaisses anfibolíticos caracterizam-se macroscopicamente pela alternância de bandas milimétricas a decimétricas, constituídas por minerais siálicos e fêmicos. As zonas claras, de textura granoblástica, têm como constituintes essenciais plagioclásio $\left(\mathrm{An}_{25}\right.$ a $A n_{60}$ ) e quartzo. Nas bandas escuras predominam os anfibólios castanhos e incolores, plagioclásios e clinopiroxênios. Ocorrem, acessoriamente, granada, opacos, biotita, clorita e epídoto. A principal textura existente é a nematoblástica; as relações texturais entre anfibólios e piroxênios são as mesmas observadas nos anfibolitos e hornblenda metagabros.

2) A consangüinidade das rochas básicas e ultrabásicas e comparação química do Complexo Pien com outros tipos característicos Ressaltou-se em capítulo anterior que as rochas magmáticas 
originais do complexo sofreram a ação de várias fases metamórficas, iniciando-se pelo metamorfismo de fácies granulito, seguido por outros eventos, causadores de anfibolitização parcial, a qual atingiu principalmente as rochas de composição gabróide, de esteatização e de serpentinização. Exceção feita a estes dois últimos eventos, o estudo petrográfico e mineralógico sugeriu a possibilidade de que as eventuais modificações metassomáticas sofridas nos processos metamórficos anteriores não teriam sido de amplitude suficiente de modo a modificar profundamente a composição global das rochas. Se tal assertiva for válida, é possível tecerem-se considerações de ordem química entre as rochas básicas e ultrabásicas originais, visando o estabelecimento de possíveis relações consangüineas entre elas.

Viu-se no capítulo de geologia local que evidências de campo forneceram os primeiros indícios dessa consangüinidade em razão da íntima associação de rochas básicas e ultrabásicas nas várias lentes. A segunda manifestação do fenômeno deve-se à elaboração da Fig. 3. Esse diagrama relaciona os teores de albita e anortita normativos com o parâmetro:

$$
\frac{\mathrm{Fe}^{2+}+\mathrm{Mn}}{\mathrm{Fe}^{2+}+\mathrm{Mn}+\mathrm{Mg}} \times 100
$$

e foi proposto por Wager (1960) para indicar a existência de fracionamento do magma basáltico. Tal fenômeno ocorre com o aumento da quantidade de $\mathrm{Fe}^{2+}$ em relação ao $\mathrm{Mg}$ e com a elevação do índice normativo

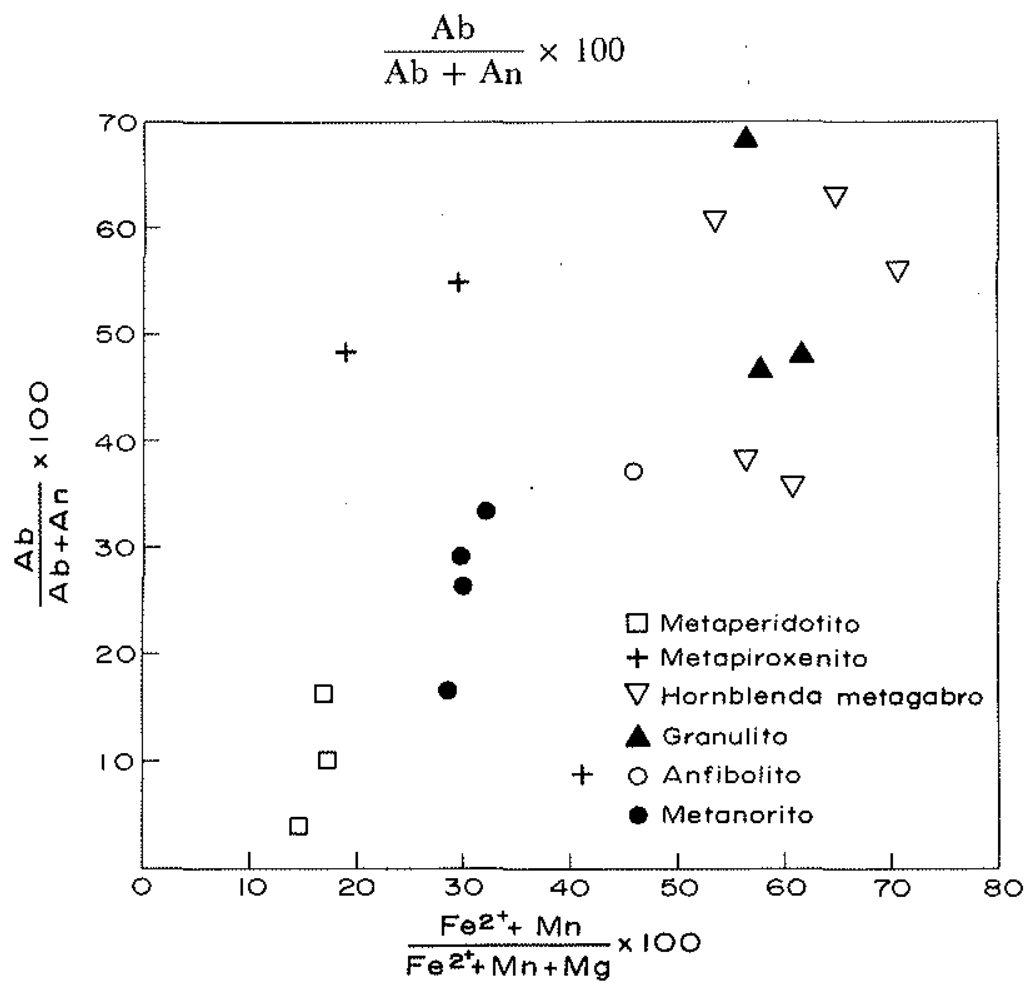

Figura 3 - Relação entre os parâmetros

$$
\frac{\mathrm{Ab}}{\mathrm{Ab}+\mathrm{An}} \times 100 \mathrm{e} \frac{\mathrm{Fe}^{2+}+\mathrm{Mn}}{\mathrm{Fe}^{2+}+\mathrm{Mn}+\mathrm{Mg}} \times 100
$$

nas rochas básicas e ultrabásicas de Pien 
à medida que a diferenciação progride. Posteriormente, estendeu-se o uso desse gráfico para constatar-se a presença ou a ausência de consangüinidade entre rochas básicas e ultrabásicas (Weedeon, 1970). Projetadas nesse diagrama (Fig. 3; Tabela I), as amostras de Pien dispuseram-se de modo a não permitir, entre si, a existência de espaços vazios que pudessem sugerir a existência de vários magmas.

As amostras do complexo básico-ultrabásico de Pien foram também colocadas em diagrama triangular, cujos vértices são ocupados por ferro, magnésio e álcalis, respectivamente (Fig. 4). A análise dessa figura evidencia, inicialmente, enriquecimento gradual em ferro, principalmente, e também em álcalis à medida que a basicidade das rochas diminui. A relação $\mathrm{Mg} / \mathrm{Fe}$ muito alta nos serpentinitos e metaperidotitos, dada a presença de serpentina, olivina e ortopiroxênio nessas rochas, decai nos metapiroxenitos. Próximos a esse grupo, e ainda mais pobres em $\mathrm{Mg}$, aparece o anfibólito. As razóes $\mathrm{Mg} / \mathrm{Fe}$ mais baixas e os teores de álcalis mais altos ocorrem nos hornblenda metagabros e granulitos.

Comparou-se, em seguida, o trend das amostras de Pien com os campos de composição dos complexos de Skaegaard, reproduzido por Bowes et al. (1970), de Maryland, EUA, e de Vourinon, Grécia, ambos reproduzidos por Thayer (1967). Enquanto Skaegaard é exemplo típico de complexo estratiforme, Maryland e Vourinon retratam, segundo Thayer (1967), exemplos de maciços alpinos. Observando-se a Fig. 4 é possível notar que as amostras de Pien coincidem em sua grande maioria com os campos de composição dos complexos Maryland e Vourinon.

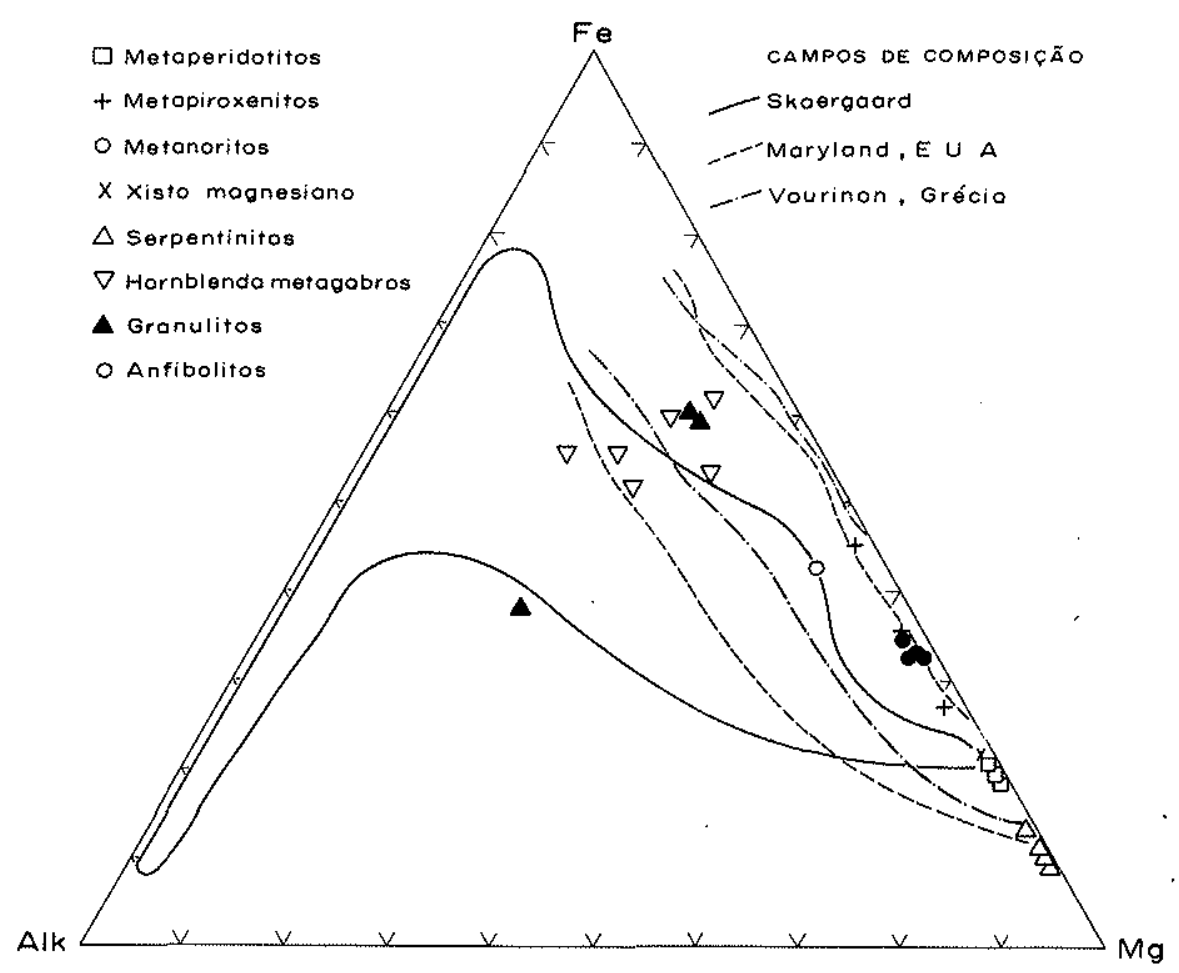

Figura 4 - Relação percentual de $\mathrm{Fe}, \mathrm{Mg}$ e Al nas rochas de Pien. Comparação entre esses valores e campos de composição de outros complexos básicos-ultrabásicos 
Tabela I - Análise química de rochas

\begin{tabular}{|c|c|c|c|c|c|c|c|c|c|c|c|c|c|c|}
\hline \multirow[b]{2}{*}{$\mathrm{s} 1 \mathrm{O}_{2}$} & \multicolumn{3}{|c|}{ Metaperidotitos } & \multicolumn{3}{|c|}{ Metapíroxenitas } & \multicolumn{4}{|c|}{ Metanoritos } & \multicolumn{4}{|c|}{ Serpentinitos } \\
\hline & 47,86 & 46,14 & 44,32 & 49,90 & 46,90 & 52,40 & 49,07 & 49,63 & 51,70 & 50.60 & 39,86 & 39,09 & 40,97 & 39,07 \\
\hline $\mathrm{Al}_{2} \mathrm{O}_{3}$ & 6,90 & 5,90 & 8,23 & 3,32 & 7,40 & $3,6 B$ & 11,13 & 10,06 & 7,91 & 9,20 & 0,80 & 0,85 & 0,89 & 1,15 \\
\hline $\mathrm{T} \mathrm{O}_{2}$ & 0,09 & 0,06 & 0,07 & 0,35 & $0,7 \xi$ & 0,42 & 0,29 & 0,29 & 0,28 & 0,30 & - & 0,02 & 0,02 & 0,06 \\
\hline Feo & 5,38 & 5,20 & $5,2 t$ & 3,50 & 9,70 & 5.40 & 6,68 & 6,80 & 7,21 & 6,60 & 0,72 & 1,08 & 2,17 & 1,81 \\
\hline $\mathrm{Fe}_{2} \mathrm{O}_{3}$ & 1,70 & 3,80 & 3,34 & 4,60 & 3,47 & 3,56 & 3.00 & 3,22 & 3,05 & 3,90 & 6,21 & 6,38 & 4,65 & 5,14 \\
\hline $\mathrm{CaO}$ & 2,44 & 1,75 & 2,40 & 16,20 & 12,43 & 17,10 & 8,01 & 8,00 & 7,31 & 6,40 & 0,02 & 0,02 & 0,02 & 0,04 \\
\hline $\mathrm{MgO}$ & 33,70 & 34,00 & 32,71 & 20,20 & 17,25 & 16,47 & 20,50 & 19,50 & 21,94 & 21,70 & 39,20 & 39,33 & 38,60 & 39,64 \\
\hline $\mathrm{Na}_{2} \mathrm{O}$ & 0,06 & 0,19 & 0,15 & 0,61 & 0,20 & 0,85 & 1,13 & 1.20 & 0,69 & 0,50 & 0,03 & 0,03 & 0,31 & 0,30 \\
\hline $\mathrm{K}_{2} \mathrm{O}$ & - & 0,01 & 0,01 & 0,24 & 0,57 & 0,04 & 0,02 & 0,05 & 0,20 & 0,05 & - & - & 0,01 & 0,03 \\
\hline $\mathrm{P}_{2} \mathrm{O}_{3}$ & - & - & - & - & 0,02 & " & - & - & - & - & " & - & - & - \\
\hline mo & 0,02 & 0,02 & 0,02 & 0,11 & 0,16 & 0,18 & 0,02 & 0,18 & 0,01 & 0,20 & 0,06 & 0,08 & 0,09 & 0,04 \\
\hline $\mathrm{H}_{2} \mathrm{O}^{+}$ & 1,08 & 2,70 & 3,48 & 0,50 & 1,04 & 0,52 & 0,19 & 0,85 & 0,20 & 1,08 & 12,30 & 12,74 & 11,55 & 12,49 \\
\hline TOTAL & 99,23 & 99,77 & 99.74 & 99.53 & 99,85 & 100,62 & 100,04 & 99,78 & 100,50 & 100,53 & 99,20 & 99,62 & 99.28 & 99,77 \\
\hline$\frac{100\left(\mathrm{FeO}^{\circ}+\mathrm{Fe}_{2} \mathrm{O}_{3}\right)}{\mathrm{Fe} 0+\mathrm{Fe}_{2} \mathrm{O}_{3}+\mathrm{Mg}^{\mathrm{d}}}$ & 17,4 & 20,9 & 19,8 & 28.6 & 43,3 & 35,2 & 32,1 & 34,0 & 31,9 & 32,6 & 15,0 & 15,9 & 15,0 & 14,9 \\
\hline$\frac{\mathrm{Fe}^{2+}+\mathrm{Mn} \times 100}{\mathrm{Mg}+\mathrm{Fe}^{2+}+\mathrm{Mn}}$ & 17 & 16 & 17 & 18 & 42 & 30 & 30 & 32 & 30 & 29 & 2 & 3 & 6 & 5 \\
\hline
\end{tabular}

\begin{tabular}{|c|c|c|c|c|c|c|c|c|c|c|c|}
\hline \multirow[b]{2}{*}{$\mathrm{SiO}_{2}$} & \multirow{2}{*}{$\begin{array}{c}\text { Anf ibolito } \\
43,80\end{array}$} & \multirow{2}{*}{$\begin{array}{c}\text { Talco Xisto } \\
63,20\end{array}$} & \multicolumn{6}{|c|}{ Hornblenda Metagabros } & \multicolumn{3}{|c|}{ Granulitos } \\
\hline & & & 45,69 & 50,26 & 51,00 & 46,06 & 49,34 & 45,80 & 52,00 & 52,95 & 52,96 \\
\hline $\mathrm{Al}_{2} \mathrm{O}_{3}$ & 14,90 & 0,10 & 17,16 & 16,25 & 20,26 & 16,51 & 13.50 & 17.80 & 16,01 & 15.74 & 19,60 \\
\hline $\mathrm{riO}_{2}$ & 1,04 & 0,05 & 0,73 & 2,32 & 0,99 & 0,80 & 0,65 & 1,10 & 0,79 & 0,60 & 0,68 \\
\hline Fe0 & 7,20 & 2,84 & 8,99 & 7,94 & 5,42 & 8,57 & 7,57 & 8,60 & 9,01 & 6,65 & 4,30 \\
\hline $\mathrm{Fe}_{2} \mathrm{O}_{3}$ & 6,30 & 0,76 & 5,62 & 3,20 & 3,84 & 2,80 & 5,90 & 4,51 & 0,85 & 4,33 & 1,90 \\
\hline $\mathrm{CaO}$ & 10,05 & 0,04 & 11,12 & 7,18 & 7,86 & 10,60 & 10,55 & 10,60 & 11,20 & 10,47 & 6,95 \\
\hline $\mathrm{MgO}$ & 11,30 & 27,90 & 7,53 & 5,49 & 3,43 & 8,50 & 7,13 & 6,52 & 6,54 & 5,47 & 4,28 \\
\hline $\mathrm{Na}_{2} \mathrm{O}$ & 2,40 & 0,11 & 2,26 & 4,20 & 4,80 & 3,34 & 3,90 & 2,87 & 2,97 & 2,99 & 7,00 \\
\hline $\mathrm{K}_{2} \mathrm{O}$ & 0,78 & 0.10 & 0,20 & 1,40 & 1,39 & 0,82 & 1,16 & 1,10 & 0,25 & 0.09 & 1,24 \\
\hline $\mathrm{P}_{2} \mathrm{O}_{5}$ & 0,05 & - & - & 0,68 & 0,71 & 0,11 & - & - & 0,02 & - & 0,22 \\
\hline MnO & 0,20 & $0,02$. & 0,22 & 0,02 & 0,15 & 0.18 & 0,21 & 0,22 & 0,20 & 0,02 & 0,10 \\
\hline $\mathrm{H}_{2} \mathrm{O}^{+}$ & 1,50 & 4,95 & 0,03 & 0,20 & 0,40 & $\$, 60$ & 0,25 & 0,70 & 0.30 & 0,16 & 1,04 \\
\hline TOTAE. & 99,52 & 100.07 & 99,55 & 99,14 & 100,25 & 99,89 & 100,18 & 99,82 & 100,14 & 99,47 & 100,27 \\
\hline$\frac{100\left(\mathrm{FeO}+\mathrm{Fe}_{2} \mathrm{O}_{3}\right)}{\mathrm{FeO}+\mathrm{Fe}_{2} \mathrm{O}_{3}+\mathrm{HgO}_{9}}$ & 54,4 & 11,4 & 66,0 & 67,0 & 73,0 & 57.2 & 65,3 & 69,9 & 60,1 & 66,7 & 59,2 \\
\hline $\mathrm{Fe}^{2+}+\mathrm{Mn} \times 100$ & 46 & 12 & 61 & 65 & 71 & 57 & 53 & 65 & 58 & 62 & 57 \\
\hline
\end{tabular}

3) As fases metamórficas O primeiro evento metanórfico caracterizado na região de Pien refere-se ao ciclo Transamazônico em condiçőes de fácies granulito. O'Hara et al. (1971) discutem as condições de formação de granada peridotitos e de espinélio peridotitos. De acordo com esses autores, granada peridotitos são metaestáveis na crosta continental normal. Tais ocorrências ou resultaram do manto, em razão de transporte tectônico através de dezenas de quilômetros, ou originam-se in situ em razão de metamorfismo de peridotitos preexistentes na crosta. Neste caso as condiç̋̃es seriam excepcionais, pois o fenômeno só poderia ocorrer a profundidades e pressões superiores, respectivamente, a $40 \mathrm{~km} \mathrm{e}$ $12 \mathrm{~kb}$. De outro lado, espinélio peridotitos, em particular espinélio lherzolitos, são comuns em terrenos granulíticos. Tal associação posicionar-se-ia entre a base da crosta normal (pressões de 8-10 kb) e a zona de granada peridotito no manto superior (pressões de 12-15 kb).

Assim, é de esperar o aparecimento de espinélio peridotitos em zonas profundamente erodidas e escudos continentais. A região de Pien caracteriza-se por exposiçőes do embasamento e parece ser parte de núcleo antigo. As rochas ultramáficas são comumente portadoras de espinélio, não tendo sido constatada qualquer amostra de granada peridotito. 
Durante o ciclo Brasiliano os fenômenos ocorridos na região caracterizaram-se, presumivelmente, por temperaturas mais baixas. Nas rochas básicas o efeito preponderante foi a intensa anfibolitização. As rochas graníticas, porém, sofreram fusões parciais, resultando em nova migmatização regional e na formação do Granito Agudos. A presença de enclaves básicos perfeitamente conservados nesse corpo mostra que, apesar da grande disponibilidade de água, a temperatura não foi suficiente para fundi-los. Deformações nas rochas básicas e ultrabásicas, representadas por cisalhamento (visível principalmente em serpentinitos, em vários hornblenda metagabros e anfibolitos) e por estruturas xistosas e texturas nematoblásticas nos anfibolitos, teriam permitido percolação mais fácil de fluidos, facilitando, desse modo, a hidratação dos minerais.

As rochas ultramáficas foram fortemente afetadas por esteatização e serpentinização. As evidências texturais indicam ser os piroxênios os principais responsáveis pela formação de talco e tremolita, componentes principais dos xistos magnesianos. Admite-se ter havido, durante essa reação, alguma introdução de $\mathrm{SiO}_{2}$, proveniente possivelmente dos migmatitos encaixantes, concomitante com saída de $\mathrm{CaO}$. O trabalho de Fyfe (1962) mostra que o limite máximo de estabilidade do talco situa-se abaixo de $730^{\circ} \mathrm{C}$.

Olivinas foram os principais minerais primários responsáveis pela formação de serpentina nas rochas de Pien. As temperaturas de serpentinização têm sido objeto de numerosas pesquisas. O trabalho pioneiro foi executado por Bowen e Tuttle (1949) relativo ao estudo do sistema $\mathrm{MgO}-\mathrm{SiO}_{2}-\mathrm{H}_{2} \mathrm{O}$. Esses autores concluíram que à pressão abaixo de $1 \mathrm{~kb}$, serpentina e brucita se formam a partir de forsterita abaixo de $400^{\circ} \mathrm{C}$. Sob pressão de $3 \mathrm{~kb}$ a reação se processa a $450^{\circ} \mathrm{C}$. Pistorius (1963) estudou o fenômeno a $50 \mathrm{~kb}$ e determinou que a temperatura de transição se situa a $475^{\circ} \mathrm{C}$. Scarfe e Wyllie (1967) introduziram ferro no sistema e concluíram que serpentinas portadoras desse elemento são estáveis até $300^{\circ} \mathrm{C}$ e $325^{\circ} \mathrm{C}$, a pressões de 1 a $3 \mathrm{~kb}$, respectivamente. Johannes (1968) refez essa pesquisa e assinalou que as verdadeiras temperaturas de transição situam-se acerca de $60^{\circ} \mathrm{C}$ abaixo. Barnes e $\mathrm{O}^{\prime} \mathrm{Neil}$ (1969) afirmam que serpentinas podem se formar a temperaturas próximas da temperatura ambiente, sob efeito de alteração intempérica. Discute-se muito na literatura se a serpentinização precede a esteatização ou se a ordem dos fenômenos é invertida. Hess (1933) e Chidester (1962) acreditam na primeira hipótese. Versalo (1965) e Page (1967) representam os autores que defendem a segunda.

Os estudos experimentais acima relacionados mostram que a esteatização e a serpentinização ocorrem a temperaturas abaixo de $730^{\circ} \mathrm{C}$ e $475^{\circ} \mathrm{C}$, respectivamente. No caso de Pien, pode-se supor que os fenômenos tenham se iniciado durante o ciclo Brasiliano, dada a disponibilidade de água existente. No que tange à relação cronológica entre os fenômenos deve-se levar em conta as seguintes relações texturais:

a) em algumas seções notou-se que a talcificação precedeu a serpentïnização,

b) na maioria das amostras observadas, não se notou indicação de que um dos processos tenha antecedido o outro, parecendo que a única correlação válida se refere à natureza do mineral original (olivina ou ortopiroxênio) e

c) vários serpentinitos permitem supor ter havido mais uma geração de serpentina.

A observação dessas texturas, aliada às temperaturas experimentais, indicam que, numa fase inicial, teria se iniciado a talcificação. Com o decréscimo de temperatura, após atingido determinado limite (abaixo de $475^{\circ} \mathrm{C}$ ), cujo valor exato depende da pressão de água atuante, iniciou-se a serpentinização. Portanto, ambos os fenômenos teriam ocorrido concomitantemente durante determinado tempo. É possivel que várias fases de serpentinização tenham existido, correspondentes a temperaturas decrescentes. 
AGRADECIMENTOS O autor agradece ao Conselho Nacional de Desenvolvimento Científico e Tecnológico (CNPq) e à Fundação de Amparo à P'esquisa do Estado de São Paulo (FAPESP) pela ajuda financeira prestada.

\section{BIBLIOGRAFIA}

ALbUQUERQUE, L. F. F., ARIOLI, E. E., DIAS, A. H. e KIRCHNER, C. A. - 1971 - Geologia das Quadrículas de Blumenau e Joinville, SC. DNPM/GPRM (inédito), Porto Alegre, RS

ALLARD, G. O. e FUJIMORI, K. - 1966 - A new occurrence of sapphirine in Salvador, Bahia, Brazil. Canad. Mineral. 8, p. 660

BARNES, I. e O'NEIL, J. R. - 1969 - The relationship between fluids and some fresh alpine-type ultramafics and possible serpentinization, Western United States. Bull. Geol. Soc. Am. 80: 1947.1960

BERBERT, G. O. - 1970 - Geologia dos complirxos básicos-ultrabásicos de Goiás. An. XXIV (a)ngr. Bras. Geol., pp. 42-i0. Barailia

BOWEN, N. L. e TUTTLE, O.F. - 1949 - The system $\mathrm{MgO}-\mathrm{SiO}_{2}-\mathrm{H}_{2} \mathrm{O}$. Bull. Geol. Soc. Am. 60: 439.460

BOWES, D. R., SKINNER, W. R. e WRIGHT, A.E. - 1970 - Petrochemical comparation of the Bushveld Igneous Complex with some other mafic complexes. The Geol. Soc. of South Alrica. Sp. Publ. 1: $425-440$

BOYD, F. R., Jr. e MacGREGOR, I. O. - 1964 - Ultramafic rocks. Carnegie Inst. Wash. Yearbook 63: 152-157

BRITO NEVES, B. B. e ALBUQUERQUE, J. P. T. - 1973 - Geologia e províncias hidrológicas de Santa Gatarina. An. XXVII Congr. Bras. Geol. (no prelo), Aracaju

CHIDESTER, A.H. - 1962 - Petrology and geochemistry of selected talcbearing ultramafic rocks and adjacent country rocks in North Central Vermont, U. S. Geol. Prof. Paper, 345

CORDANI, U. G. - 1971 - Síntese da geocronologia precambriana da região costeira atlântica meridional da América do Sul. XXV Congr. Bras. Geol., Bol. Especial n. ${ }^{\circ}$ 1, pp. 179-180, São Paulo

CORDANI, U, G. - 1974 - Comentários sobre as determinações geocronologicas disponíveis nas Folhas Asunción e Curitiba - Carta Geol. do Brasil ao Milionésimo (Folhas Asunción e Curitiba). DNPM, pp. 58-72, Brasília

CORDANI, U. G. e GIRARDI, V. A. V. - 1967 - Geologia da Folha de Morretes. Bol. da Univ. Fed. do Paraná, n. ${ }^{\circ}$ 26, Guritiba

DEER, W. A., HOWIE, R.A. e ZUSSMAN, J. - 1963 - Rocks Forming Minerals. Longmans, Londres

DEN TEX, E. - 1971 - The facies groups and facies series of metamorphism and their relation to physical conditions in the earth's crust. Lithos 4, 23-41

FUCK, R. A., TREIN, E., MURATORI, A. e RIVEREAU, J. C. - 1969 - Mapa geológico preliminar do litoral da Serra do Mar e de parte do primeiro planalto do Estado do Paraná. Bol. Paran. Geoc. 27, Curitiba

FYFE, W.S. - 1962 - On the relative stability of talc, anthophyllite and enstatite. A. J. Sc. 260 , $460-466$

GIRARDI, V.A.V. - 1974 - Petrologia do complexo básico-ultrabásico de Pien, PR. Tese de livre-docência (inédito), Instituto de Geociências, USP

GIRARDI, V.A. V., CORDANI, V., CANDIDO, A., MELFI, A.J. e KAWASHITA, K. 1974 - Gcocronologia do complexo básico-ulirabásico de Pien, PR. Anais XXVIII Congresso Brasileiro de Geologia, Porto Alegre (prelo)

HESS, H. H. - 1933 - Hydrotermal metamorplism of an ultrabasic intrusive of Schuyler, Virginia. Amer, J. Sc., Serv. 5, p. 337

JOHANNES, W. - $1968-$ Experimental investigation of the reaction forsterite $+\mathrm{H}_{2} \mathrm{O} \rightarrow$ serpentine + brucite. Contr. Miner. Petrol. 19, 309-315

KRETZ, R. - 1966 - Interpretation of the shape of mineral grains in metamorphic rocks. J. Petrol. 7, 68-94 
LEAKE, B.E. - 1968 - A catalog of analysed calciferous and subcalciferous amphiboles togheter with their nomenclature and associated minerals. Geol. Soc. Am.. Sp. Paper 98, 1-210

MARINI, O.J., FUCK, R. A. e TREIN, E. - 1967 - Intrusivas básical Jurássico-Cretáceas no primeiro planalto do Paraná - Geologia do predevoniano e intrusivas subseqüentes da porção oriental do Estado do Paraná. Bol. Paran. Geoc. 23-25, pp. 307.323

MARINI, O.J., TREIN, E. e FUCK, R. A. - 1970 - Folha Geológica de Mandiruba - Com. Carta Geol. do Paraná, Curitiba, PR

MINIOLI, B. - 1972 - Aspectos geológicos da região litorânea Piçarras-Barra Velha, SG. Tese de Doutoramento (inédito), Instituto de Geociências, USP

O'HARA, M.J., RICARDSON, S. W. e WILSON, G. - 1971 - Garnet-peridotite - stability and occurrence in crust and mantle. Contr. Mineral and Petrol. 32, 48-68

PAGE, N. J. - 1967 - Serpentinization at Burro Mountain, California. Gontr. Mineral, and Petrol. 14: $321-342$

PISTORIUS, C. W.F.T. - 1963 - Some phase relations in the system $\mathrm{MgO}^{-} \mathrm{SiO}_{2}-\mathrm{H}_{2} \mathrm{O}$ to high pressures and temperatures. Neus J. Mineral. Monatsh 11: 283-293

RENGER, F. - 1972 - As rochas ultrabásicas da Serra do Espinhaço, MG. Rev. Bras. Geoc. 2(3): $151-160$

SCARFE, C. M. c WYLLIE, P.J. (1967) - Serpentine dehydration curves and their hearing on serpentine deformation in orogenesis. Nature, Lond. 215, pp. 945-946

SCHULTZ Jr., A., ALBUQUERQUE, L. F. e GIFFONI, L. E. - 1969 - Gcologia da quadrícula de Rio do Sul, Santa Catarina. DNPM (inédito). Porto Alegre, RS, 109 pp.

SCORZA. F. P. - 1968 - Distribuição das rochas ultrabásicas no Brasil. An. Acad. Briı, Ciênc., 40 (suplemento), 119-126

STORMER Jr., J. C. - 1973 - The composition of saphirine from Salvador, Bahia, and conditions of its formation, Rev. Bras. Geol. 3 (3): 192-200

THAYER, T.P. - 1967 - Chemical and structural relations of ultramafic and feldspatic rocks in alpine intrusive complexes, in: Willie, J.P. (ed.) Ultramafic and Related Rocks, New York, $381-392$

TREIN, E., FUCK, R. A. : MURATORI, A. - 1969a - Folha Geologica de Tijucas do Sul, Paraná. Com. Carta Góológica do Paraná, Curitiba, PR

TREIN, E., MURATORI, A., BASUMALLICK, S., FUCK, R. A. e MARINI, O.J. - 1969b - Folha Geológica de Pien. Com. Carta Geológica do Paraná, Curitiba, PR

VERSA1.(. I. - 1965 - Talc shists and soapstone occurrences of Finlande. Bull. Comm. Geol. Finland 216

WAGER, L. R. - 1960 - The relationship between the fractionation stage of basalt magma and the temperature of the beginning of its crystallization. Geoch. et Cosmoch. Acta 21 (2): 158-160

WEEDON, D. S. - 1970 - The ultrabasic igneous rocks of the Huntly region. Scott J. Geol. 6(1): $26-40$

WILSON, A. F. e HUDSON, D. R. - 1967 - The discovery of beryllium bearing sapphirine in the granulites of the Misgrave ranges (Central Australia). Chem. Geol. 2: 209-215

WYLLIE, J. P. - 1967 - Petrogenesis of ultramafic and ultrabasic rocks - a review, in: Wyllie, J. P. (ed), Ultramafic and Related Rocks, New York, 403-415 